\title{
A Different, Different Direction
}

\author{
Jason Baird Jackson ${ }^{1}$ \\ Indiana University \\ ${ }^{1}$ Department of Folklore and Ethnomusicology \\ Indiana University \\ Classroom Office Building \\ Bloomington IN 47405 United States \\ jbj@indiana.edu
}

\begin{abstract}
In an editorial, Museum Anthropology Review editor Jason Baird Jackson discusses new developments for the journal, highlighting its new status as a publication of the Indiana University Press. The move of the journal's publishing home from the Mathers Museum of World Cultures to the Indiana University Press necessitates reversing an editorial plan previously announced. As has been true for all but the past year of its history, the journal welcomes scholarly and practitioner contributions from across the full breadth of the fields of museum anthropology, museum-based folklore studies, and material culture studies.
\end{abstract}

\section{Keywords}

archaeological museums; anthropology; editing; ethnological museums; journals (periodicals); public folklore; publishers; publishing; universities and colleges. Topical keywords are drawn from the American Folklore Society Ethnographic Thesaurus, a standard nomenclature for the ethnographic disciplines.

\section{Competing Interests}

The author declares no competing interests.

\section{License}

Creative Commons CC BY-NC-SA 4.0

Museum Anthropology Review Volume 14,1-2 (Spring-Fall 2020), pp 1-5 eISSN 1938-5145

https://scholarworks.iu.edu/journals/index.php/mar Copyright (c) Jason Baird Jackson 2020. All rights reserved. For editorial inquiries, e-mail: mar1@indiana.edu 


\title{
A Different, Different Direction
}

\author{
Jason Baird Jackson \\ Indiana University
}

\begin{abstract}
In an editorial, Museum Anthropology Review editor Jason Baird Jackson discusses new developments for the journal, highlighting its new status as a publication of the Indiana University Press. The move of the journal's publishing home from the Mathers Museum of World Cultures to the Indiana University Press necessitates reversing an editorial plan previously announced. As has been true for all but the past year of its history, the journal welcomes scholarly and practitioner contributions from across the full breadth of the fields of museum anthropology, museum-based folklore studies, and material culture studies.
\end{abstract}

[Keywords: archaeological museums; anthropology; editing; ethnological museums; journals (periodicals); public folklore; publishers; publishing; universities and colleges. Topical keywords are drawn from the American Folklore Society Ethnographic Thesaurus, a standard nomenclature for the ethnographic disciplines.]

Sometimes plans change. Writing in the midst of a global COVID-19 pandemic that is severely impacting the United States, this truism feels like a daily experience. In the most recent issue of Museum Anthropology Review (MAR), I published an editorial in which I discussed the journal's thirteen-year history and I outlined a new direction for it (Jackson 2019a). That new direction was grounded in the idea that, as the journal of Indiana University's Mathers Museum of World Cultures, MAR could better serve the mission of the museum if it more closely aligned with the institution's own specific projects and partnerships. The issue in which my editorial appeared reflected that vision. That issue centered on five project reports, four of which related directly to the work of the museum or its partners. ${ }^{1}$ The vision that I offered made sense at the time that my editorial was authored and the issue was assembled. MAR was then in its seventh year as the scholarly journal of the Mathers Museum of World Cultures. Editing it was then one of my duties as the museum's director. The realignment that I envisioned sought to make the journal more directly connected to the work of the museum and to best steward limited museum resources. I think that plan made good sense in its own terms and in its own moment and context, but the purpose of this new editorial is to reverse course.

In late August 2019, I learned that the Mathers Museum of World Cultures would be incorporated into a new museum. That new museum was announced in September 2019 and is now known as the Indiana University Museum of Archaeology and Anthropology (IUMAA). Under the leadership of a new Executive Director and pursuing a new institutional mission emphasizing in the archaeology of the North American 
Midwest, the IUMAA, as the inheritor of MAR and all other Mathers Museum assets, agreed to transfer the journal to the Indiana University Press in November 2019. My time as Director of the Mathers Museum of World Cultures formally concluded at the end of December 2019. MAR and I both find ourselves in a new and unanticipated era. I begin by noting that, while unforeseen, this new era holds out tremendous promise for the journal and for me. I am happy to share a renewed vision for the journal here. Throughout my editorships of, first, Museum Anthropology and then of Museum Anthropology Review, I was very sparing in the publishing of editorials. There is something perversely funny about my publishing two in a row and having those two editorials intentionally contradict one another. With the passage of a bit of time and the formulation of new plans, I am encouraged now by what this all means for MAR. I hope that you will be encouraged also.

In terms of content, what was old is new again. MAR again welcomes submissions from scholars and practitioners working across the full breadth of the global fields of museum anthropology, museum-based folklore studies, and material culture studies. The pages of MAR have featured many wonderful contributions over the years and it is exciting to think about the innovative, substantive, engaging work that can appear here in the years ahead. Proposals for theme sections and issues are very welcome and submissions across the journal's range of genres-particularly scholarly articles and project reports-are very much encouraged. In its new era, it is my hope that the journal will reflect and foster the diversity of museum-based and museum-focused work emerging in its fields and the diversity of scholars and practitioners active around the world. In a time of profound global social change, I aspire for MAR to be a resource for those who want to open up new conversations and to make new interventions related to the state of museums and material cultures, past, present, and especially future. As has been true for MAR in the past, I will try, whenever possible, to publish in languages other than English. I am especially eager, where appropriate, to publish scholarly work written in the Indigenous languages of the Americas.

MAR will also resume soliciting book, exhibition, and digital media reviews. I take this opportunity to thank the scores of colleagues who have labored to produce thoughtful and engaging reviews for MAR over the past fourteen years. I also want to pause to thank the many peer-reviewers whose hard work and careful judgements have so profoundly shaped the articles appearing in MAR across these years. Reviewers of both types will be essential partners as the journal enters the new period now beginning.

The commitment to open access publishing practices that has characterized MAR since its founding will also remain unchanged as the Indiana University Press takes up work publishing the journal. The Press is a unit of the Indiana University Libraries and the libraries have been with MAR since day one. I am thankful for the staff of the Scholarly Communication department at the IU Libraries for facilitating the publication of MAR before and during its Mathers Museum period. The Scholarly Communication department, which operates the IUScholarWorks Journals platform based on the open source publishing platform Open Journal Systems, will now partner with IU Press in support of the Press' work as MAR's publisher. This is really a wonderful development because it combines all of the strengths that have underpinned MAR in its first thirteen years with unique press publishing capacities and staff talents that will, I think, springboard MAR to new heights. There are more of these than I can innumerate, but they will include enhancements to backhouse publishing practices, to indexing and discoverability, to promotion, and to the reader experience. The issue 
that you are reading, with MAR's first professional, original design, is a tangible token of the enhancements that the Press will bring to MAR as its new owner.

Another benefit of the IU Press being MAR's publisher relates to continuity. Under the care of the IU Libraries, digital preservation of MAR content has always been robust. This remains unchanged with the IU Press as MAR's publisher and owner. Where the press can provide new continuity is relative to the office of editor. As MAR's founding editor, I have now been involved in its publication for a very long time as these things go. I am thankful that the IU Press has asked me to continue as MAR's editor and I am excited to guide the journal at the start of the new period described here. But I am also eager to work with the press to prepare for the time when the journal is handed off to a new editor, to a pair of co-editors, or to an editorial collective. Museums can be publishers, for sure. Great museums often include great publishing programs, but when it comes to journal publishing, a great journal publisher like IU Press has unique capabilities. These include the ability to work with journal editors recruited on a worldwide basis.

Such succession questions will advance in the background in the years ahead. For now, I am happy to report that the editorial office for MAR is returning to my academic home in Indiana University's Department of Folklore and Ethnomusicology. As a professor in it, in IU's Department of Anthropology, and in my campus' interdepartmental graduate program in Curatorship, there will continue to be rich local contexts that will enliven and animate the journal's work. As was true before the journal's move to the museum, I am confident that MAR will be positively impacted by the richness of Indiana University's work in museum and material culture studies. Within its departmental and interdepartmental context, MAR will be a project of the Material Culture and Heritage Studies Laboratory, a departmental research group that I established in July 2020. Beyond my campus, I am eager to make MAR a useful resource for new conversations taking place in many organizations within which museum anthropologists, museum folklorists, and interdisciplinary material culture studies scholars gather.

Museum Anthropology Review's first phase-volumes 1-6 (2007-2012)-was a time of experimentation and exploration around the affordances of open access scholarly publishing. What could we learn? What could we do? How could we connect? What might be possible with a journal founded and operated according to different goals, using new technologies, and with a self-consciously different business model. I feel good about what we learned and what we, as a community of hundreds of authors and reviewers, accomplished in that first phase. Volumes 7-13, corresponding to MAR's time (2013-2019) as a publishing project of the Mathers Museum of World Cultures, saw publication of some of the journal's most important and widely cited general contributions. Formally transferring the journal to the museum in 2013, I had imagined that it would go on without me as a key part of the institution's long-term work as a dedicated, mission-driven museum of ethnography, ethnology, and cultural history. After being personally connected with the Mathers Museum of World Cultures for almost three decades, I was disappointed that the journal and the museum would not continue in the way that I had anticipated, but this volume (14) opens up a third period in the history of the journal and this is a really exciting prospect. No longer a start-up endeavor or a DIY project held together with tape and bailing wire, the journal is now a mature scholarly publication with a worthy history and many distinctive accomplishments. That history and those accomplishments are the collective accomplishment of all of those who gathered around the journal and made it happen. 
Looking ahead, and with the resources of the IU Press behind it, now is a great time for you to submit your own work to Museum Anthropology Review. Welcome to the next chapter in MAR's story. •

\section{Note}

1. For a sense of the work of the Mathers Museum of World Cultures during the time of my directorship (2013-2019) and the time of MAR's affiliation with the museum, see Jackson 2015, 2019; Kay 2016, 2019; Otto 2019; Rogers 2019.

\section{References Cited}

Jackson, Jason Baird. 2015. "Interconnections: Folklore Studies and Anthropology at the Mathers Museum of World Cultures.” Practicing Anthropology 37(3): 20-23. https://doi.org/10.17730/0888-4552-37.3.20

—. 2019a. "Histories and Realignments: Museum Anthropology Review in a New Era." Museum Anthropology Review 13 (1-2): 1-10. https://doi.org/10.14434/mar.v13i1.26802

— 2019b. "At Home and Abroad: Reflections on Collaborative Museum Ethnography at the Mathers Museum of World Cultures.” Museum Anthropology 42 (2): 62-70. https://doi.org/10.1111/muan.12210

Kay, Jon. 2016c. "Traditional Arts Indiana at Indiana University's Mathers Museum.” Journal of Folklore and Education 3:109-12. https://locallearningnetwork.org/wp-content/uploads/States-from-JFEv3-10.pdf

—. "Traditional Arts Indiana's Bicentennial Exhibition.” Museum Anthropology Review 13 (1-2): 11-31. https://doi.org/10.14434/mar.v13i1.24990

Otto, Kristin. 2019. "Shapes of the Ancestors: Bodies, Animals, Art, and Ghanaian Fantasy Coffins.” Museum Anthropology Review 13 (1-2): 47-58.

https://doi.org/10.14434/mar.v13i1.26580

Rogers, Emily Buhrow. 2019. "Exhibiting Moments: Qualla Arts and Crafts Mutual at the Mathers Museum of World Cultures.” Museum Anthropology Review 13 (1-2): 32-46. https://doi.org/10.14434/mar.v13i1.26472

Jason Baird Jackson is Ruth N. Halls Professor of Folklore and Anthropology at Indiana University and editor of Museum Anthropology Review. He also edits the Material Vernaculars book series published by Indiana University Press. 